\title{
Nitric oxide synthase polymorphisms, gene expression and lung function in chronic obstructive pulmonary disease
}

Farzian Aminuddin ${ }^{1}$, Tillie-Louise Hackett ${ }^{1}$, Dorota Stefanowicz ${ }^{1}$, Aabida Saferali ${ }^{1}$, Peter D Paré ${ }^{1}$, Amund Gulsvik², Per Bakke², Michael H Cho ${ }^{3}$, Augusto Litonjua ${ }^{3}$, David A Lomas ${ }^{4}$, Wayne H Anderson ${ }^{5}$, Terri H Beaty ${ }^{6}$, Edwin K Silverman ${ }^{3}$ and Andrew J Sandford ${ }^{1 *}$

\begin{abstract}
Background: Due to the pleiotropic effects of nitric oxide (NO) within the lungs, it is likely that NO is a significant factor in the pathogenesis of chronic obstructive pulmonary disease (COPD). The aim of this study was to test for association between single nucleotide polymorphisms (SNPs) in three NO synthase (NOS) genes and lung function, as well as to examine gene expression and protein levels in relation to the genetic variation.

Methods: One SNP in each NOS gene (neuronal NOS (NOS1), inducible NOS (NOS2), and endothelial NOS (NOS3)) was genotyped in the Lung Health Study (LHS) and correlated with lung function. One SNP (rs1800779) was also analyzed for association with COPD and lung function in four COPD case-control populations. Lung tissue expression of NOS3 mRNA and protein was tested in individuals of known genotype for rs 1800779 . Immunohistochemistry of lung tissue was used to localize NOS3 expression.

Results: For the NOS3 rs1800779 SNP, the baseline forced expiratory volume in one second in the LHS waS significantly higher in the combined AG + GG genotypic groups compared with the AA genotypic group. Gene expression and protein levels in lung tissue were significantly lower in subjects with the AG + GG genotypes than in AA subjects. NOS3 protein was expressed in the airway epithelium and subjects with the AA genotype demonstrated higher NOS3 expression compared with AG and GG individuals. However, we were not able to replicate the associations with COPD or lung function in the other COPD study groups.
\end{abstract}

Conclusions: Variants in the NOS genes were not associated with lung function or COPD status. However, the G allele of rs 1800779 resulted in a decrease of NOS3 gene expression and protein levels and this has implications for the numerous disease states that have been associated with this polymorphism.

Keywords: Chronic obstructive pulmonary disease, Nitric oxide synthase, Polymorphism, Gene expression

\section{Background}

Nitric oxide (NO) is a molecule that is involved in many physiological and pathological pathways and can have either beneficial or detrimental effects. Many studies have shown that NO has protective effects on human airways such as muscle relaxation, attenuation of airway hyper-responsiveness to bronchoconstrictor stimuli, and the killing of invading microorganisms [1]. In contrast,

\footnotetext{
* Correspondence: andrew.sandford@hli.ubc.ca

${ }^{1}$ The University of British Columbia James Hogg Research Centre, Providence Heart + Lung Institute, Vancouver, Canada

Full list of author information is available at the end of the article
}

adverse effects of NO have also been observed, such as vasodilation of the bronchial circulation, increased airway secretions and the promotion of pro-inflammatory pathways, as well as necrosis and apoptosis [1].

Endogenous NO is primarily synthesized by enzymes known as NO synthases (NOS) which catalyze the cellular production of NO from arginine. There are three known NOS isoforms: neuronal NOS (NOS1), inducible NOS (NOS2), and endothelial NOS (NOS3). In humans, NOS1 can be found in neurons and endothelial cells in the lung [2], while NOS3 is found in bronchiolar epithelial cells and the endothelium $[3,4]$. NOS2 is expressed in the

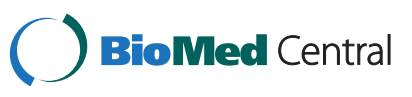


human airway epithelium [5], lung endothelium [2], and alveolar macrophages [2].

Due to its pleiotropic effects, it is likely that NO is a significant factor in the pathogenesis of lung diseases such as chronic obstructive pulmonary disease (COPD), which is characterized by airflow limitation that is not fully reversible. There is evidence to suggest that NOS genes are associated with COPD. Recently, the mRNA and protein expression of NOS1 and NOS2 were observed to be increased in the peripheral lung tissue of smokers with COPD compared with nonsmoker controls, whereas the opposite effect was detected for NOS3 expression [6]. Another study reported that the numbers of $\mathrm{NOS}_{2}{ }^{+}$and $\mathrm{NOS}^{+}$cells were increased in the bronchial submucosa of smokers with COPD compared with nonsmoker controls [7]. Furthermore, deficiency of NOS2 has been shown to be protective against cigarette smoke-induced emphysema in a mouse model [8].

To further determine the effects of NOS in COPD, it is important to determine whether single nucleotide polymorphisms (SNPs) in NOS genes are associated with phenotypes related to the disease. It has been widely acknowledged that genetic factors account for some of the variability of lung function among smokers $[9,10]$, suggesting an interaction between genetic and environmental influences on disease progression. The aim of this study was to determine whether NOS gene variants were associated with phenotypes related to COPD. We examined the rate of decline of lung function and baseline lung function in smokers with mild to moderate airflow obstruction from the Lung Health Study (LHS) in relation to polymorphisms in three NOS genes. The LHS was a randomized trial of an anti-smoking intervention and bronchodilator treatment in volunteer smokers [11]. We selected polymorphisms in NOS genes that had previously been associated with gene function or COPD-related traits [12-14]. We sought to determine whether these polymorphisms were associated with lung function decline and baseline level in COPD patients in the LHS as well as with COPD and lung function in four replication case-control sets.

\section{Methods}

\section{Ethics statement}

The investigation of the LHS and lung tissue samples was approved by the University of British Columbia/Providence Health Care Research Ethics Board and all subjects provided written informed consent. We attempted to replicate the associations in subjects from the following previously recruited populations: Norway COPD Cohort (GenKOLS) [15], National Emphysema Treatment Trial (NETT) [16,17], Normative Aging Study (NAS) [18], Evaluation of COPD Longitudinally to Identify Predictive Surrogate Endpoints (ECLIPSE) [19] and COPDGene [20]. These studies were approved by the relevant institutional review boards and all subjects provided written informed consent. For the NAS, anonymized data were used, as approved by the institutional review boards of Partners Healthcare System and the Boston VA.

\section{Study participants}

The participants in the primary analysis were from the National Heart, Lung, and Blood Institute sponsored LHS cohort [11], consisting of smokers who had mild/moderate lung function impairment at the start of the study. Table 1 provides the characteristics of the LHS participants. Of the 5887 total participants in the LHS cohort, 4132 individuals of Caucasian descent had DNA samples available for the study. Lung function at the start of the study was expressed as forced expiratory volume in 1 second $\left(\mathrm{FEV}_{1}\right)$ as a percentage of predicted value. The change in lung function, measured as change in $\mathrm{FEV}_{1} \%$ predicted per year over a five-year period, was also an outcome measure of this study. For gene expression in lung tissue, genomic DNA, mRNA and protein were isolated from lung tissue from Caucasian patients who had undergone lobar or lung resection surgery for a localized lung cancer $(n=27)$. These samples were obtained from the James Hogg Research Centre Lung Registry. SNPs that showed association with lung function in the LHS cohort were genotyped in four Caucasian case-control cohorts: 1) the first 1000 COPDGene study subjects, 2) the COPD cases and smoking controls of the ECLIPSE study, 3) the NETT cases and NAS controls, and 4) the GenKOLS case-control population from Norway (Table 2) as described previously [21].

\section{Gene variants and genotyping}

SNP selection was based on previous genetic associations with disease and function (Table 3). The NOS1 SNP (rs41279104) is located in the exon 1c regulatory region. Both the NOS2 SNP (rs8078340) and the NOS3 SNP (rs1800779) are located in their respective promoter regions. DNA from blood samples of the LHS participants was whole genome amplified using the REPLI-g Mini Kit (Qiagen, Mississauga, ON, Canada) prior to genotyping.

Table 1 Characteristics of the $\mathbf{4 1 3 2}$ Lung Health Study participants (2611 male, 1521 female)

\begin{tabular}{|c|c|}
\hline Characteristic & Total \\
\hline Age (mean $\pm S D$ ), years & $48.5 \pm 6.7$ \\
\hline Smoking history (mean \pm SD), pack-years ${ }^{a}$ & $40.4 \pm 18.4$ \\
\hline 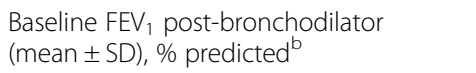 & $78.55 \pm 9.10$ \\
\hline $\begin{array}{l}\mathrm{FEV}_{1} \text { post-bronchodilator rate of decline } \\
(\text { mean } \pm \mathrm{SD}), \% \text { predicted / year }{ }^{\mathrm{C}}\end{array}$ & $-0.97 \pm 1.78$ \\
\hline
\end{tabular}

${ }^{a}$ Number packs of cigarettes smoked per day $\times$ number of years of smoking. ${ }^{b}$ Lung function at the start of the study measured as forced expiratory volume in 1 second $\left(F E V_{1}\right)$.

${ }^{\mathrm{C}} \mathrm{Change}$ in lung function over a five-year period measured as forced expiratory volume in 1 second $\left(F E V_{1}\right)$. 
Table 2 Characteristics of the case-control replication study groups

\begin{tabular}{|c|c|c|c|c|c|c|c|c|}
\hline \multirow[t]{2}{*}{ Characteristic } & \multicolumn{2}{|l|}{ COPDGene } & \multicolumn{2}{|l|}{ ECLIPSE } & \multicolumn{2}{|l|}{ NETT/NAS } & \multicolumn{2}{|l|}{ GenKOLS } \\
\hline & Cases & Controls & Cases & Controls & Cases & Controls & Cases & Controls \\
\hline Number of participants & 499 & 501 & 1764 & 178 & 373 & 435 & 863 & 808 \\
\hline Age (mean $\pm S D$ ), years & $64.77 \pm 8.12$ & $60.20 \pm 8.66$ & $63.63 \pm 7.10$ & $57.48 \pm 9.44$ & $67.47 \pm 5.78$ & $69.8 \pm 7.49$ & $65.53 \pm 10.03$ & $55.62 \pm 9.71$ \\
\hline $\begin{array}{l}\text { Smoking history (mean } \pm \text { SD), } \\
\text { pack-years }^{a}\end{array}$ & $54.76 \pm 26.69$ & $38.87 \pm 21.07$ & $50.29 \pm 27.42$ & $32.11 \pm 24.84$ & $66.43 \pm 30.68$ & $40.66 \pm 27.85$ & $31.98 \pm 18.46$ & $19.66 \pm 13.58$ \\
\hline $\begin{array}{l}\mathrm{FEV}_{1}(\text { mean } \pm \mathrm{SD}) \\
\% \text { predicted }^{\mathrm{b}}\end{array}$ & $48.73 \pm 18.41$ & $97.98 \pm 11.32$ & $47.63 \pm 15.62$ & $107.83 \pm 13.56$ & $28.12 \pm 7.38$ & $99.97 \pm 13.20$ & $50.63 \pm 17.44$ & $94.91 \pm 9.24$ \\
\hline Sex (\% male) & $49.5 \%$ & $50.1 \%$ & $67.0 \%$ & $57.9 \%$ & $63.8 \%$ & $100 \%$ & $60.1 \%$ & $50.1 \%$ \\
\hline
\end{tabular}

${ }^{a}$ Number packs of cigarettes smoked per day $\times$ number of years of smoking.

${ }^{b}$ Lung function was measured as forced expiratory volume in 1 second $\left(F E V_{1}\right)$ as a percentage of the predicted value.

The following TaqMan assays (Applied Biosystems, Foster City, CA, USA) were used: assay ID for rs41279104 $=\mathrm{C}$ 86363451_10; rs8078340 =C_29024700_10; rs1800779= C_7599687_1. For each assay, 5 ng of DNA was used for allelic discrimination. For genome-wide SNP genotyping in the COPDGene, ECLIPSE, NETT-NAS, and GenKOLS populations, all cohorts were genotyped on Illumina platforms (Human Hap550, Quad610, and Omni1 Quad). Quality control in each cohort included subject missingness, discordances, relatedness, and sex; and marker missingness, discordances, singletons, and Hardy-Weinberg equilibrium.

\section{Quantitative polymerase chain reaction (PCR)}

RNA was extracted from lung tissue samples using the RNeasy Mini Kit (Qiagen) and cDNA was synthesized using SuperScript ${ }^{\oplus}$ III Reverse Transcriptase (Life Technologies, Grand Island, NY, USA). The cDNA samples were used to determine the gene expression of NOS3. The reference gene used was GNB2L1 as this was previously shown to be stably expressed in lung tissue [22]. Gene expression assays for NOS3 (Hs01574659_m1) and GNB2L1 (Hs00272002_m1) were purchased from Applied Biosystems. Gene expression was calculated using cycle threshold (CT) values for NOS3 and GNB2L1, as previously described [23].

\section{Protein expression levels}

Human lung tissue fragments $(30 \mathrm{mg}$ ) were homogenized in protein extraction buffer with protease and phosphatase inhibitors (Sigma-Aldrich, St. Louis, MO, USA). Protein lysates were resolved by SDS-PAGE and transferred to nitrocellulose membranes, and probed with anti NOS3 rabbit polyclonal antibody NOS3 (C-20): sc-654 at a concentration of $200 \mu \mathrm{g} / \mathrm{mL}$ (Santa Cruz Biotechnology, Inc., Santa Cruz, CA, USA) and anti- $\beta$-tubulin monoclonal antibody clone AA2 at a concentration of $1 \mathrm{mg} / \mathrm{mL}$ (Upstate Co., Lake Placid, NY, USA). Detection was performed with IR700 and IR800 anti-mouse and antirabbit antibodies (Cell Signaling Technology, Danvers, MA, USA). The density of the bands was analyzed with the Odyssey Infrared Imaging System (LI-COR Biotechnology, Lincoln, NE, USA) using two infrared channels independently. The results were expressed as NOS3 / $\beta$-tubulin density ratios.

\section{Immunohistochemistry}

Sections were de-paraffinized, rehydrated, and antigen retrieved by autoclaving $\left(15 \mathrm{~min}, 120^{\circ} \mathrm{C}, 30 \mathrm{psi}\right)$ for $20 \mathrm{~min}$ in citrate target retrieval solution (Dako, Mississauga, $\mathrm{ON}$, Canada). Endogenous peroxidase was quenched with 3\% $\mathrm{H}_{2} \mathrm{O}_{2}$ and non-specific interactions blocked for $20 \mathrm{~min}$ with $10 \%$ goat serum. Antibody directed against human NOS3 (NOS3 (C-20): sc-654, Santa Cruz Biotechnology, Inc.) at $200 \mu \mathrm{g} / \mathrm{mL}$ was added overnight at $4^{\circ} \mathrm{C}$ in $5 \%$ goat serum. Sections were then incubated with biotinylated goat anti-mouse (1:100, Vector Labs Burlingame, CA, USA) for $60 \mathrm{~min}$ followed by a $10 \mathrm{~min}$ treatment with Streptavidin-HRP (Dako). The NOS3 antigen was visualized using the brown chromogen 3, 3-diaminobenzidine (Dako) and counterstained with Harris Hematoxylin Solution (Sigma-Aldrich). Finally, sections were then dehydrated and mounted with Cytoseal 60 (Richard-Allan Scientific, Kalamazoo, MI, USA). Antibody dilutions and all washes were in TRIS-buffered saline solution.

Table 3 Description of the polymorphisms studied

\begin{tabular}{|c|c|c|c|c|c|}
\hline Gene & SNP & Protein & Allele change & Location & Association \\
\hline NOS1 & rs41279104 & Neuronal NOS & $C=>T$ & Promoter for exon $1 \mathrm{c}$ & Reduced gene expression [12] \\
\hline NOS2 & rs8078340 & Inducible NOS & $G=>A$ & Promoter region & Decreased DNA-protein complex [13] \\
\hline NOS3 & rs1800779 & Endothelial NOS & $A=>G$ & Intronic & Lower FEV $1 \%$ predicted in COPD patients [14] \\
\hline
\end{tabular}




\section{Statistical analyses}

The JMP 5.1 statistical software package (SAS Institute Inc., Cary, NC, USA) was used for analysis of the relationship between the genetic variants and the measures of lung function in the LHS. Agreement of the genotype distributions with Hardy-Weinberg equilibrium was assessed using a $\mathrm{X}^{2}$ goodness-of-fit analysis. The two outcomes used in the LHS were baseline and rate of decline of post-bronchodilator $\mathrm{FEV}_{1}$, expressed as a percent of predicted value. Statistical analyses were performed by multiple linear regression. For the COPDGene, ECLIPSE, NETT-NAS, and GenKOLS, after removal of principal component outliers, genotype imputation within each study was performed using $\mathrm{MaCH}$ and $\mathrm{CEU}$ samples from HapMap2 and the 1000 Genomes Project as a reference population. Association analysis of SNPs with casecontrol status was performed in each cohort using logistic regression, adjusting for age, pack-years of cigarette smoking, and genetic ancestry using PLINK 1.07. Results were combined among the four cohorts using fixed effect meta-analyses using METAL and R 2.12 (manuscript submitted). Differences in gene expression and protein levels between the three genotypes were assessed using two-tailed t-tests.

\section{Results}

Allelic discrimination in the lung health study

None of the three SNPs were in Hardy-Weinberg equilibrium for their genotypic distributions in the Caucasian LHS population (rs41279104, $\mathrm{p}$-value $=0.04$; rs8078340, $\mathrm{p}$-value $=0.008 ; \mathrm{rs} 1800779, \mathrm{p}=0.003)$. We did not detect any association of either the rs41279104 or the rs8078340 polymorphisms with baseline $\mathrm{FEV}_{1}$ or rate of decline of $\mathrm{FEV}_{1}$ (Table 4). However, there was an association of the rs1800779 SNP with baseline lung function $(p=0.0018)$ (Table 4). This result remained significant $(\mathrm{p}=0.0108)$ after Bonferroni correction for multiple comparisons (3 SNPs and 2 outcomes). In particular, subjects with the GG genotype had higher baseline $\mathrm{FEV}_{1}$ compared with subjects who had the AA genotype $(p=0.0273)$. Furthermore, with the AG + GG genotypes combined, an association with an increase in baseline $\mathrm{FEV}_{1}$ was observed compared with the AA genotype $(\mathrm{p}=0.0042)$. No significant association, however, was observed with rate of decline of $\mathrm{FEV}_{1}$. An association study of this SNP was then performed in the four replication case-control populations; however no significant findings were observed (Table 5). In addition, we examined the relationship of $\mathrm{rs} 1800779$ to $\mathrm{FEV}_{1}$ \% predicted in the four replication populations but there was no significant association with lung function in either the cases or the controls (Table 6).

\section{NOS3 mRNA expression in lung tissue}

Since we had observed an association between the NOS3 rs1800779 polymorphism and lung function levels in the LHS, a follow-up experiment was performed to determine the effect of rs1800779 on NOS3 gene expression in lung tissue. Individuals were closely matched for age and sex among each genotype ( 7 males and 2 females for each genotype; average age $60 \pm 6$ years in all 3 groups). Of the subjects where smoking status was known, they were either ex-smokers $(n=12)$ or current smokers $(n=9)$. No association with NOS3 gene expression was observed when all three genotypes were analyzed. However, as shown in Figure 1, subjects with the AG + GG genotypes combined demonstrated significantly lower NOS3 gene expression in comparison with the AA genotype $(\mathrm{p}=0.0366)$.

\section{NOS3 protein levels in lung tissue}

The same lung tissue samples used for NOS 3 mRNA expression were subsequently utilized for protein analysis

Table 4 Genotype frequencies of NOS polymorphisms among participants in the LHS cohort and their associations with lung function

\begin{tabular}{|c|c|c|c|c|c|c|c|c|c|c|}
\hline Gene & SNP & Genotype & $\mathbf{N}$ & $\begin{array}{l}\text { Mean } \pm \text { SE } \\
\text { Baseline FEV } 1 \\
\text { (\% predicted) }\end{array}$ & $p$-value ${ }^{* a}$ & $p$-value ${ }^{* b}$ & $\mathbf{N}$ & $\begin{array}{l}\text { Mean } \pm \text { SE Rate } \\
\text { of Decline in } \\
\text { FEV }_{1} \text { (\% predicted) }\end{array}$ & $p$-value ${ }^{* a}$ & p-value ${ }^{* b}$ \\
\hline \multirow[t]{3}{*}{ NOS1 } & rs41279104 & CC & 2650 (79\%) & $78.39 \pm 0.17$ & Referent & 0.1424 & 2602 (79\%) & $-0.97 \pm 0.04$ & Referent & 0.3530 \\
\hline & & $\mathrm{CT}$ & $650(19 \%)$ & $78.84 \pm 0.37$ & 0.7688 & & $635(19 \%)$ & $-1.02 \pm 0.07$ & 0.5332 & \\
\hline & & $\pi$ & $55(2 \%)$ & $79.33 \pm 1.19$ & 0.3825 & & $52(2 \%)$ & $-1.27 \pm 0.26$ & 0.3434 & \\
\hline \multirow[t]{3}{*}{ NOS2 } & rs8078340 & GG & $2760(76 \%)$ & $78.64 \pm 0.17$ & Referent & 0.1118 & $2705(76 \%)$ & $-0.96 \pm 0.03$ & Referent & 0.1838 \\
\hline & & $A G$ & $794(22 \%)$ & $78.28 \pm 0.32$ & 0.7166 & & $781(22 \%)$ & $-1.03 \pm 0.07$ & 0.8221 & \\
\hline & & AA & $81(2 \%)$ & $77.82 \pm 1.00$ & 0.2977 & & $81(2 \%)$ & $-1.12 \pm 0.20$ & 0.4215 & \\
\hline \multirow[t]{3}{*}{ NOS3 } & rs1800779 & AA & $1448(41 \%)$ & $77.97 \pm 0.24$ & Referent & 0.0018 & 1425 (41\%) & $-1.05 \pm 0.05$ & Referent & 0.3838 \\
\hline & & $A G$ & $1552(44 \%)$ & $78.81 \pm 0.23$ & 0.8034 & & 1521 (44\%) & $-0.92 \pm 0.05$ & 0.1149 & \\
\hline & & GG & $516(15 \%)$ & $79.31 \pm 0.39$ & 0.0273 & & $504(15 \%)$ & $-1.02 \pm 0.07$ & 0.7133 & \\
\hline
\end{tabular}

*p-values were adjusted for age, sex, and smoking history (pack-years).

ap-value for comparison to the wild type homozygous genotype.

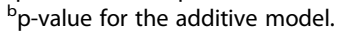


Table 5 Genetic association of NOS3 rs1800779 SNP with COPD affection status in each case-control study

\begin{tabular}{|c|c|c|c|c|c|}
\hline Genotype & $\begin{array}{l}\text { COPDGene } \\
\beta \text { coefficient } \\
\text { (SE) p-value* }\end{array}$ & $\begin{array}{l}\text { ECLIPSE } \\
\beta \text { coefficient } \\
\text { (SE) p-value }{ }^{*}\end{array}$ & $\begin{array}{l}\text { NETT/NAS } \\
\beta \text { coefficient } \\
\text { (SE) p-value }\end{array}$ & $\begin{array}{l}\text { GenKOLS } \\
\beta \text { coefficient } \\
\text { (SE) } p \text {-value } \text { - }^{*}\end{array}$ & $\begin{array}{l}\text { Meta-analysis } \\
\beta \text { coefficient } \\
\text { (SE) } p \text {-value* }\end{array}$ \\
\hline AA & Referent & Referent & Referent & Referent & Referent \\
\hline AG & $0.03(0.15) 0.83$ & $0.01(0.19) 0.95$ & $0.36(0.19) 0.06$ & $0.03(0.13) 0.81$ & $0.08(0.08) 0.30$ \\
\hline GG & $0.15(0.22) 0.49$ & $0.13(0.28) 0.6310$ & $0.10(0.27) 0.70$ & $-0.05(0.19) 0.79$ & $0.07(0.12) 0.57$ \\
\hline
\end{tabular}

*p values were adjusted for age, pack-years of cigarette smoking, and genetic ancestry.

by western blot. As shown in Figure 2, subjects with the rs1800779 AG + GG genotypes combined demonstrated significantly lower levels of NOS3 in comparison with individuals who had the AA genotype $(p=0.0002)$. We then used immunohistochemical analysis of lung tissue from three randomly selected donors of each genotype to localize NOS3 expression. As shown in Figure 3, the staining demonstrated NOS3 protein expression predominantly within the airway epithelium and again subjects with AA genotype demonstrated higher NOS3 expression compared with AG and GG individuals.

\section{Discussion}

In this study we investigated three polymorphisms in the NOS genes in relation to cross-sectional lung function and rate of decline of lung function in COPD patients. Although we observed a significant association with rs1800779 in NOS3 with baseline lung function in the derivation cohort we were unable to replicate the association in additional patient groups. Nevertheless, we were able to demonstrate that the rs1800779 SNP has a functional effect on the expression of the NOS3 gene and this has implications for the numerous disease states that have been associated with this polymorphism [24-27].

The NOS gene variants that we investigated were limited to those that had strong a priori evidence for involvement in regulation of gene expression or in a trait related to COPD. We utilized this approach to maximize power by limiting the number of comparisons that were made. If a tag SNP approach had been used, a total of 137 polymorphisms would have had to be genotyped (using a minor allele cut off of $1 \%$, an $\mathrm{r}^{2}$ cut off for linkage disequilibrium of 0.8 in the European population, and a region $10 \mathrm{~kb}$ up- and downstream of each gene). Thus, the correction for multiple comparisons would be substantially more severe and the power of the study greatly reduced. The rationale for the SNP selection is described below.

The NOS1 rs41279104 polymorphism that was selected for this study was previously shown to be associated with reduced gene expression [12]. The minor (T) allele was associated with a $30 \%$ reduction in expression in a reporter gene assay [12]. The minor (A) allele of the NOS2 rs8078340 polymorphism was associated with considerably decreased affinity for nuclear protein(s) [13] suggesting that it has functional significance. We prioritized these polymorphisms for investigation in this study, as we reasoned that these functional effects could be relevant to a variety of traits, including COPD. The rs1800779 polymorphism in NOS3 was associated with COPD status and lower $\mathrm{FEV}_{1} \%$ predicted in COPD patients [14]. This is the only published report of a NOS polymorphism associated with our disease of interest in the Caucasian population.

The rs1800779 polymorphism has been previously associated with a number of additional phenotypes but only one of these traits, cytokine responses in children at risk for asthma, was related to respiratory disease [24]. $r s 1800779$ is in strong LD $\left(r^{2}>0.8\right)$ with ten other polymorphisms but none of these have been associated with phenotypes related to lung function or pulmonary disease.

Table 6 Genetic association of NOS3 rs1800779 SNP with FEV F $_{1} \%$ predicted in each case-control study

\begin{tabular}{|c|c|c|c|c|c|c|}
\hline Group & Genotype & $\begin{array}{l}\text { COPDGene } \\
\beta \text { coefficient } \\
\text { (SE) p-value* }\end{array}$ & $\begin{array}{l}\text { ECLIPSE } \\
\beta \text { coefficient } \\
\text { (SE) p-value* }\end{array}$ & $\begin{array}{l}\text { NETT/NAS } \\
\beta \text { coefficient } \\
\text { (SE) p-value* }\end{array}$ & $\begin{array}{l}\text { GenKOLS } \\
\beta \text { coefficient } \\
\text { (SE) p-value* }\end{array}$ & $\begin{array}{l}\text { Meta-analysis } \\
\beta \text { coefficient } \\
\text { (SE) } p \text {-value }{ }^{*}\end{array}$ \\
\hline \multirow[t]{3}{*}{ Cases } & $\mathrm{AA}$ & Referent & Referent & Referent & Referent & Referent \\
\hline & $A G$ & 0.75 (1.84) 0.68 & $-1.43(0.85) 0.09$ & $-1.46(0.84) 0.08$ & $1.50(1.30) 0.25$ & $0.80(0.52) 0.12$ \\
\hline & GG & 2.08 (2.60) 0.42 & $-0.52(1.23) 0.67$ & $-1.42(1.17) 0.23$ & $-2.03(2.04) 0.32$ & $-0.88(0.75) 0.24$ \\
\hline \multirow[t]{3}{*}{ Controls } & $A A$ & Referent & Referent & Referent & Referent & Referent \\
\hline & $A G$ & $1.69(1.10) 0.12$ & $3.53(2.35) 0.13$ & $-0.49(1.37) 0.72$ & $-0.98(0.68) 0.15$ & $-0.09(0.52) 0.86$ \\
\hline & GG & $-0.73(1.64) 0.66$ & $0.36(3.47) 0.92$ & $-1.62(1.81) 0.37$ & $-0.12(1.05) 0.91$ & $-0.51(0.78) 0.51$ \\
\hline
\end{tabular}

*p values were adjusted for age, pack-years of cigarette smoking, and genetic ancestry. 


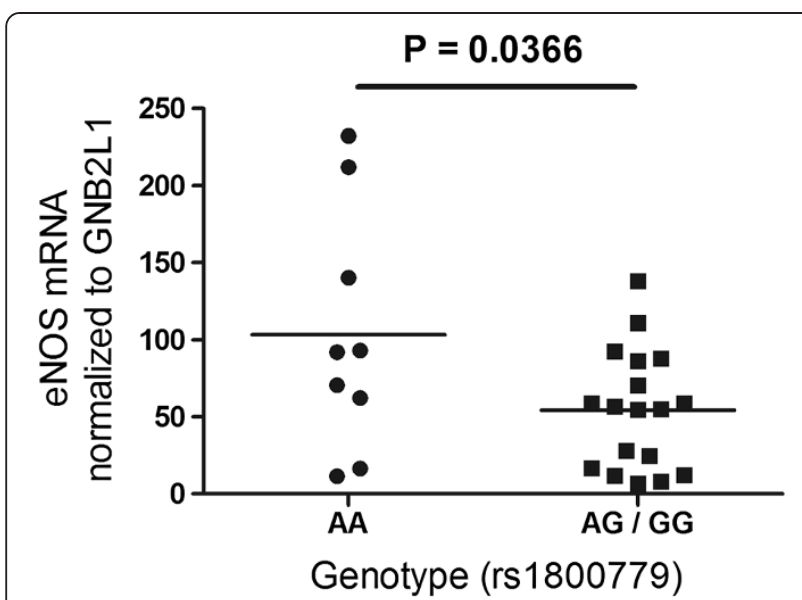

Figure 1 The effect of rs 1800779 on NOS3 mRNA expression in lung tissue.

Other NOS polymorphisms have been investigated with respect to phenotypes related to COPD. Arif et al. [14] studied four NOS3 polymorphisms in north Indian COPD patients and controls: $-786 \mathrm{~T} / \mathrm{C}$ (rs3918161), -922A/G (rs1800779), 894G/T (rs1799983), and the 4B/4A variable number of tandem repeats (VNTR). rs3918161, rs1800779 and the VNTR were associated with COPD. However, data from the HapMap project (http://hapmap.ncbi.nlm.nih.gov/) show that rs3918161 is not polymorphic in individuals of
European descent. It was not feasible to genotype the VNTR with the large sample sizes in this study and therefore rs1800779 was the only relevant polymorphism in our study populations.

Ahsan et al. investigated NOS3 rs1799983 in 27 COPD patients and 66 controls but there was no significant difference $(p=0.18)$ in genotype frequency between the groups [28]. An earlier study that examined the NOS3 VNTR did not find an association with COPD although there was an association with pulmonary hypertension in the patients [29]. Novoradovsky and colleagues genotyped six NOS3 SNPs in patients with $\alpha_{1}$-antitrypsin deficiency and found that rs1799983 and rs1549758 were increased in severely affected cases compared with healthy controls [30]. However, these associations were not confirmed by a subsequent study of $\alpha_{1}$-antitrypsin deficient patients [31] and none of our patients were $\alpha_{1}$-antitrypsin deficient. NOS 2 polymorphisms have been investigated in the context of lung function growth and childhood asthma [32]. These investigators included 24 SNPs in their analysis - seven of which were in the NOS 2 promoter. The haplotype block including the promoter SNPs was associated with incident asthma and impaired lung function growth during adolescence. However, as the associations were seen in children and were with asthma, the relevance to COPD, a disease affecting an older demographic with a different pathology, is not clear. Several studies have examined the relationship

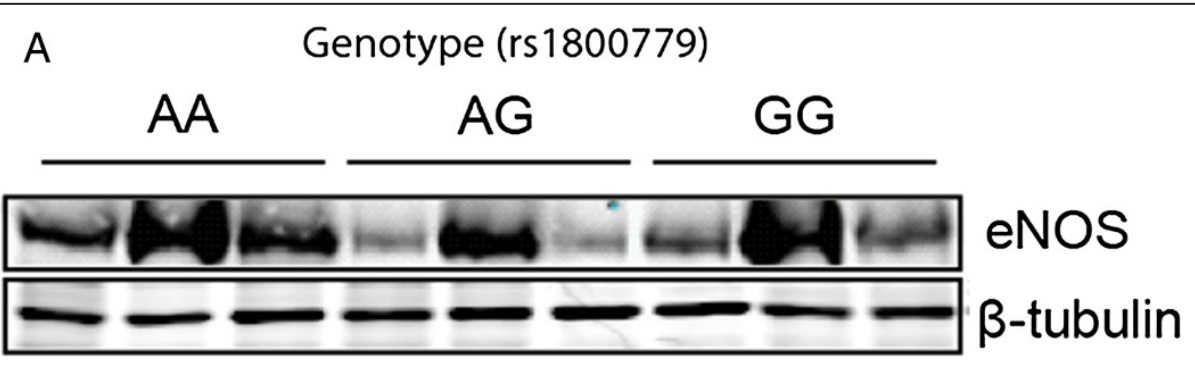

B

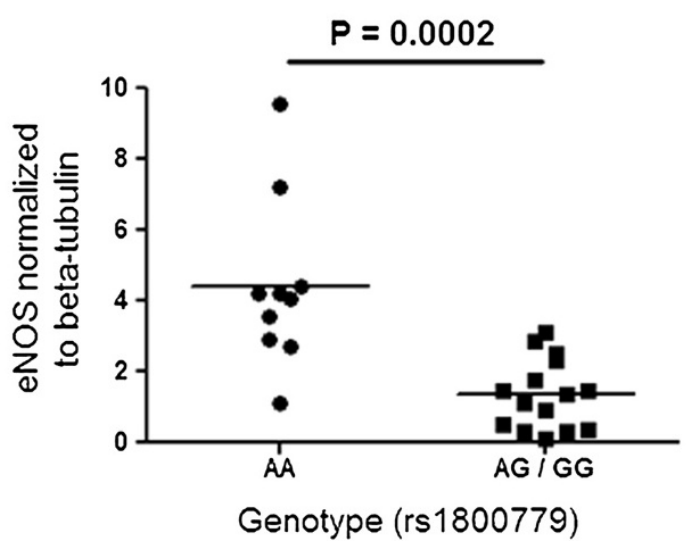

Figure 2 The effect of rs 1800779 on NOS3 protein levels in lung tissue. A) Representative western blots of NOS3 protein levels in lung tissue using 3 randomly selected subjects from each genotype. B) NOS3 protein levels normalized to $\beta$-tubulin in different rs 1800779 genotypic groups. 


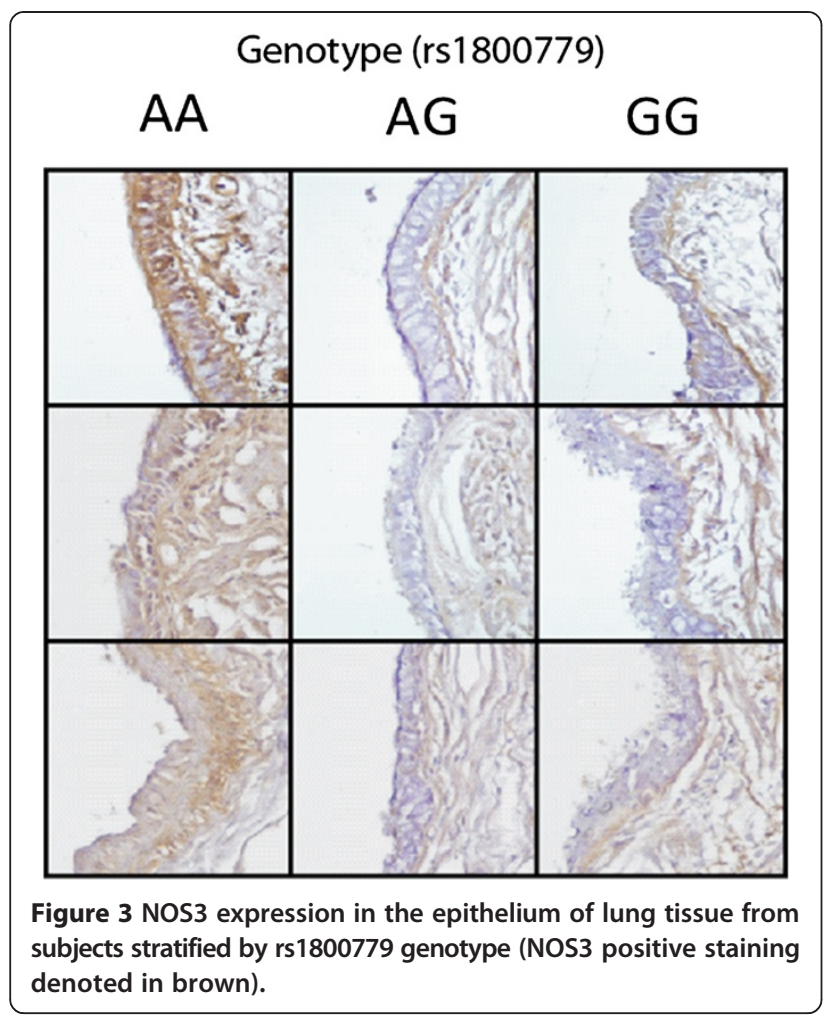

between NOS gene variants and the fraction of exhaled $\mathrm{NO}$ in asthmatics and/or healthy subjects but the results have not been consistent [33-40] and therefore we did not consider them in this study.

The NOS1 and NOS2 polymorphisms that we investigated were both associated with functional effects on their respective gene expression $[12,13]$. Therefore, we hypothesized that these variants could be important factors in COPD, and that an association of these variants with $\mathrm{FEV}_{1}$ would be observed in smokers. However, we found no significant associations between the NOS1 and NOS2 polymorphisms and lung function in COPD patients.

The rs1800779 polymorphism in the promoter of NOS3 was associated with lung function in the LHS participants. This SNP was not in Hardy-Weinberg equilibrium; however this could be due to several factors including random chance, genotyping assay failure, population stratification or because the SNP has a true genetic effect. In this study, it is unlikely a genotyping assay failure occurred since the positive controls were in $100 \%$ concordance with genotypes from the HapMap database $(n=73)$. The HapMap genotypes were generated with different technologies than the one used in this study and therefore the concordance is strongly indicative that the genotypes are accurate. Furthermore, approximately $13 \%$ of the subjects were re-genotyped and were in $100 \%$ concordance with the initial genotype results $(n=573)$. In addition, the LHS subjects were selected based on the presence of mild/moderate COPD and therefore the testing for Hardy-Weinberg equilibrium in this cohort may not be appropriate.

The results of the study in the LHS cohort demonstrated that the rs1800779 G allele was associated with a higher baseline $\mathrm{FEV}_{1}$. Although we found an association in the LHS we did not find any association of this SNP with COPD in four case-control populations. This may indicate that the association in the LHS is a false positive result, even though a limited number of polymorphisms were tested. Alternatively, the lack of replication may be a reflection of the different recruitment strategies and hence demographic factors in the cohorts involved e.g. the LHS participants were younger and had less severe airflow obstruction than the subjects in the other cohorts. The data presented in this study are contradictory to results in a previous paper which reported that the $G$ allele of the SNP is associated with reduced lung function in COPD [14]. A reason for this discrepancy could be differences in the study populations. The cohort used in the previous study was composed of Indian subjects, whereas the cohort in this study only included Caucasian subjects.

A follow-up experiment was performed to determine the effect of the rs1800779 SNP on NOS3 gene expression in lung tissue. It was observed that subjects who had the AG + GG genotypes had lower NOS3 gene and protein expression compared with the AA genotype. In addition, immunohistochemical analysis demonstrated higher NOS3 expression in the airway epithelium of COPD patients with the AA genotype. Taken together, these results strongly suggest that the G allele is associated with decreased NOS3 expression.

The function of $\mathrm{NO}$ as a deleterious pro-inflammatory or protective anti-inflammatory agent has yet to be fully understood. However, there is evidence that $\mathrm{NO}$ is implicated in the pathogenesis of lung diseases such as COPD. $\mathrm{NO}$ is a radical molecule that can rapidly react with superoxides, yielding a cytotoxic molecule known as peroxynitrite. This compound has been shown to be an important factor contributing to tissue damage in chronic inflammation, as well as impairing key cellular functions [41]. In particular, nitrosative stress mediated by peroxynitrite is evident in patients with COPD, suggesting the toxic compound is a key contributor to the pathogenesis of the disease [7]. Therefore, it can be speculated that once exposed to an environmental pollutant, such as cigarette smoke, airway cells and tissues experience oxidative and nitrosative stress due to production of endogenous NO.

\section{Conclusions}

Variants in the NOS genes were not associated with lung function or COPD status. However, the $\mathrm{G}$ allele of rs1800779 resulted in a decrease of NOS3 gene expression 
and protein levels and this has implications for the numerous disease states that have been associated with this polymorphism. The rs 1800779 polymorphism is also an excellent candidate for traits that are influenced by NO levels.

\section{Competing interests}

The authors declare that they have no competing interests.

\section{Authors' contributions}

FA carried out the genotyping assays, participated in the statistical analysis and drafted the manuscript. FA, TLH, PDP, and AJS participated in the design of the Lung Health Study and gene expression sections. FA, DS and AS performed the quantitative PCR, western blotting and immunohistochemistry. MHC performed the statistical analysis for the replication cohorts. AG, PB, AL, DAL, WHA, THB and EKS participated in study design, recruiting, and sample collection for the replication cohorts. All authors read and approved the final manuscript.

\section{Acknowledgements}

This work was supported by grants from the Canadian Institutes of Health Research and National Institutes of Health Grant 5R01HL064068-04. LA is the recipient of a UBC Four Year Doctoral Fellowship and an AllerGen NCE Inc. Canadian Allergy and Immune Diseases Training Award. AJS is the recipient of a Canada Research Chair in genetics and a Michael Smith Foundation for Health Research Senior Scholar Award.

The Lung Health Study was supported by contract N01-HR-46002 from the Division of Lung Diseases of the National Heart, Lung, and Blood Institute. The COPDGene ${ }^{\oplus}$ project is supported by the COPD Foundation through contributions made to an Industry Advisory Board comprised of AstraZeneca, Boehringer Ingelheim, Novartis, Pfizer, and Sunovion. The COPDGene ${ }^{\bullet}$ project is also supported by the National Heart, Lung, and Blood Institute contracts R01HL089856 and R01HL089897. The members of the COPDGene ${ }^{\bullet}$ study group include: Ann Arbor VA: Jeffrey Curtis, MD (PI), Ella Kazerooni, MD (RAD). Baylor College of Medicine, Houston, TX: Nicola Hanania, MD, MS (PI), Philip Alapat, MD, Venkata Bandi, MD, Kalpalatha Guntupalli, MD, Elizabeth Guy, MD, Antara Mallampalli, MD, Charles Trinh, MD (RAD), Mustafa Atik, MD. Brigham and Women's Hospital, Boston, MA: Dawn DeMeo, MD, MPH (Co-PI), Craig Hersh, MD, MPH (Co-PI), George Washko, MD, Francine Jacobson, MD, MPH (RAD). Columbia University, New York, NY: R. Graham Barr, MD, DrPH (PI), Byron Thomashow, MD, John Austin, MD (RAD). Duke University Medical Center, Durham, NC: Neil Maclntyre, Jr., MD (PI), Lacey Washington, MD (RAD), H Page McAdams, MD (RAD). Fallon Clinic, Worcester, MA: Richard Rosiello, MD (PI), Timothy Bresnahan, MD (RAD). Health Partners Research Foundation, Minneapolis, MN: Charlene McEvoy, MD, MPH (PI), Joseph Tashjian, MD (RAD). Johns Hopkins University, Baltimore, MD: Robert Wise, MD (PI), Nadia Hansel, MD, MPH, Robert Brown, MD (RAD), Gregory Diette, MD. Los Angeles Biomedical Research Institute at Harbor UCLA Medical Center, Los Angeles, CA: Richard Casaburi, MD (PI), Janos Porszasz, MD, PhD, Hans Fischer, MD, PhD (RAD), Matt Budoff, MD. Michael E. DeBakey VAMC, Houston, TX: Amir Sharafkhaneh, MD (PI), Charles Trinh, MD (RAD), Hirani Kamal, MD, Roham Darvishi, MD. Minneapolis VA: Dennis Niewoehner, MD (PI), Tadashi Allen, MD (RAD), Quentin Anderson, MD (RAD), Kathryn Rice, MD. Morehouse School of Medicine, Atlanta, GA: Marilyn Foreman, MD, MS (PI), Gloria Westney, MD, MS, Eugene Berkowitz, MD, PhD (RAD). National Jewish Health, Denver, CO: Russell Bowler, MD, PhD (PI), Adam Friedlander, MD, David Lynch, MB (RAD), Joyce Schroeder, MD (RAD), John Newell, Jr., MD (RAD). Temple University, Philadelphia, PA: Gerard Criner, MD (PI), Victor Kim, MD, Nathaniel Marchetti, DO, Aditi Satti, MD, A. James Mamary, MD, Robert Steiner, MD (RAD), Chandra Dass, MD (RAD). University of Alabama, Birmingham, AL: William Bailey, MD (PI), Mark Dransfield, MD (Co-PI), Hrudaya Nath, MD (RAD). University of California, San Diego, CA: Joe Ramsdell, MD (PI), Paul Friedman, MD (RAD) University of lowa, lowa City, IA: Geoffrey McLennan, MD, PhD (PI), Edwin JR van Beek, MD, PhD (RAD), Brad Thompson, MD (RAD), Dwight Look, MD. University of Michigan, Ann Arbor, MI: Fernando Martinez, MD (PI), MeiLan Han, MD, Ella Kazerooni, MD (RAD). University of Minnesota, Minneapolis, MN: Christine Wendt, MD (PI), Tadashi Allen, MD (RAD). University of Pittsburgh, Pittsburgh, PA: Frank Sciurba, MD (PI), Joel Weissfeld, MD, MPH, Carl Fuhrman, MD (RAD), Jessica Bon, MD. University of Texas Health Science Center at San Antonio, San Antonio, TX:
Antonio Anzueto, MD (PI), Sandra Adams, MD, Carlos Orozco, MD, Mario Ruiz, MD (RAD). Administrative Core: James Crapo, MD (PI), Edwin Silverman, MD, PhD (PI), Barry Make, MD, Elizabeth Regan, MD, Sarah Moyle, MS, Douglas Stinson. Genetic Analysis Core: Terri Beaty, PhD, Barbara Klanderman, PhD, Nan Laird, PhD, Christoph Lange, PhD, Michael Cho, MD, Stephanie Santorico, PhD, John Hokanson, MPH, PhD, Dawn DeMeo, MD, MPH, Nadia Hansel, MD, MPH, Craig Hersh, MD, MPH, Jacqueline Hetmanski, MS, Tanda Murray. Imaging Core: David Lynch, MB, Joyce Schroeder, MD, John Newell, Jr., MD, John Reilly, MD, Harvey Coxson, PhD, Philip Judy, PhD, Eric Hoffman, PhD, George Washko, MD, Raul San Jose Estepar, PhD, James Ross, MSc, Rebecca Leek, Jordan Zach, Alex Kluiber, Jered Sieren, Heather Baumhauer, Verity McArthur, Dzimitry Kazlouski, Andrew Allen, Tanya Mann, Anastasia Rodionova. PFT QA Core, LDS Hospital, Salt Lake City, UT: Robert Jensen, PhD. Biological Repository, Johns Hopkins University, Baltimore, MD: Homayoon Farzadegan, PhD, Stacey Meyerer, Shivam Chandan, Samantha Bragan. Data Coordinating Center and Biostatistics, National Jewish Health, Denver, CO: James Murphy, PhD, Douglas Everett, PhD, Carla Wilson, MS, Ruthie Knowles, Amber Powell, Joe Piccoli, Maura Robinson, Margaret Forbes, Martina Wamboldt. Epidemiology Core, University of Colorado School of Public Health, Denver, CO: John Hokanson, MPH, PhD, Marci Sontag, PhD, Jennifer Black-Shinn, MPH, Gregory Kinney, MPH.

The Evaluation of COPD Longitudinally to Identify Predictive Surrogate Endpoints (ECLIPSE) study (clinicaltrials.govidentifier NCT00292552; GSK code SCO104960) is funded by GlaxoSmithKline. Principal investigators and centers participating in the ECLIPSE study (NCT00292552): Bulgaria: Y. Ivanov (Pleven), and K. Kostov (Sofia); Canada: J. Bourbeau (Montreal, QC), M. Fitzgerald (Vancouver, BC), P. Hernandez (Halifax, NS), K. Killian (Hamilton, ON), R. Levy (Vancouver, BC), F. Maltais (Montreal, QC), and D. O'Donnell (Kingston, ON); Czech Republic: J. Krepelka (Prague); Denmark: J. Vestbo (Hvidovre); the Netherlands: E. Wouters (Horn and Maastricht); New Zealand: D. Quinn (Wellington); Norway: P. Bakke (Bergen); Slovenia: M. Kosnik (Golnik); Spain: A. Agusti' (Palma de Mallorca), and J. Sauleda (Palma de Mallorca); Ukraine: Y. Feschenko (Kiev), V. Gavrisyuk (Kiev), N. Monogarova (Donetsk), and L. Yashina (Kiev); UK: P. Calverley (Liverpool), D. Lomas (Cambridge), W. MacNee (Edinburgh), D. Singh (Manchester), and J. Wedzicha (London); and USA: A. Anzueto (San Antonio, TX), S. Braman (Providence, RI), R. Casaburi (Torrance CA), B. Celli (Boston, MA), G. Giessel (Richmond, VA), M. Gotfried (Phoenix, AZ), G. Greenwald (Rancho Mirage, CA), N. Hanania (Houston, TX), D. Mahler (Lebanon, NH), B. Make (Denver, CO), S. Rennard (Omaha, NE), C. Rochester (New Haven, CT), P. Scanlon (Rochester, MN), D. Schuller (Omaha, NE), F. Sciurba (Pittsburgh, PA), A. Sharafkhaneh (Houston, TX), T. Siler (St Charles, MO), E. Silverman (Boston, MA), A. Wanner (Miami, FL), R. Wise (Baltimore, MD), and R. ZuWallack (Hartford, CT). Steering committee: H. Coxson (Vancouver, Canada); L. Edwards (GlaxoSmithKline, Research Triangle Park, NC, USA); K. Knobil (cochair; GlaxoSmithKline, Research Triangle Park, NC, USA); D. Lomas (Cambridge, UK); W. MacNee (Edinburgh, UK); E. Silverman (Boston, MA, USA); R. Tal-Singer (GlaxoSmithKline, King of Prussia, PA, USA); J. Vestbo (co-chair; Hvidovre, Denmark); and J. Yates (GlaxoSmithKline, Research Triangle Park, NC, USA). Scientific committee: A. AgustI' (Barcelona, Spain); P. Calverley (Liverpool, UK); B. Celli (Boston, MA, USA); C. Crim (GlaxoSmithKline, Research Triangle Park, NC, USA); B. Miller (GlaxoSmithKline, King of Prussia, PA, USA); W. MacNee (chair; Edinburgh, UK); S. Rennard (Omaha, NE, USA); R. Tal-Singer (GlaxoSmithKline, King of Prussia, PA, USA); E. Wouters (Horn, Maastricht, the Netherlands); and J. Yates (GlaxoSmithKline, Research Triangle Park, NC, USA).

The National Emphysema Treatment Trial (NETT) was supported by the National Heart, Lung, and Blood Institute contracts N01HR76101, N01HR76102, N01HR76103, N01HR76104, N01HR76105, N01HR76106, N01HR76107, N01HR76108, N01HR76109, N01HR76110, N01HR76111, N01HR76112, N01HR76113, N01HR76114, N01HR76115, N01HR76116, N01HR76118, and N01HR76119. The NETT was also supported by the Centers for Medicare and Medicaid Services and the Agency for Healthcare Research and Quality. Co-investigators in the NETT Genetics Ancillary Study also include J. Benditt, G. Criner, M. DeCamp, P. Diaz, M. Ginsburg, L. Kaiser, M. Katz, M. Krasna, N. Maclntyre, R. McKenna, F. Martinez, Z. Mosenifar, J. Reilly, A. Ries, P. Scanlon, F. Sciurba, and J. Utz.

The Normative Aging Study (NAS) is supported by the Cooperative Studies Program/ Epidemiology Research and Information Center (ERIC) of the US Department of Veterans Affairs and is a component of the Massachusetts Veterans Epidemiology Research and Information Center (MAVERIC), Boston, Massachusetts. The Norway GenKOLS study (Genetics of Chronic Obstructive Lung Disease, GSK code RES11080) is funded by GlaxoSmithKline. 


\section{Author details}

${ }^{1}$ The University of British Columbia James Hogg Research Centre, Providence Heart + Lung Institute, Vancouver, Canada. ${ }^{2}$ Haukeland University Hospital and Institute of Medicine, University of Bergen, Bergen, Norway. ${ }^{3}$ Channing Laboratory and Pulmonary and Critical Care Medicine, Department of Medicine, Brigham and Women's Hospital and Harvard Medical School, Boston, MA, USA. ${ }^{4}$ Cambridge Institute for Medical Research, University of Cambridge, Cambridge, UK. ${ }^{5}$ GlaxoSmithKline Research and Development, Research Triangle Park, South of Durham, NC, USA. ${ }^{6}$ Johns Hopkins School of Public Health, Baltimore, MD, USA.

Received: 31 July 2013 Accepted: 31 October 2013

Published: 6 November 2013

\section{References}

1. Ricciardolo FL, Sterk PJ, Gaston B, Folkerts G: Nitric oxide in health and disease of the respiratory system. Physiol Rev 2004, 84:731-765.

2. Kobzik L, Bredt DS, Lowenstein CJ, Drazen J, Gaston B, Sugarbaker D, Stamler JS: Nitric oxide synthase in human and rat lung: immunocytochemical and histochemical localization. Am J Respir Cell Mol Biol 1993, 9:371-377

3. Shaul PW, North AJ, Wu LC, Wells LB, Brannon TS, Lau KS, Michel T, Margraf $L R$, Star RA: Endothelial nitric oxide synthase is expressed in cultured human bronchiolar epithelium. J Clin Invest 1994, 94:2231-2236.

4. Giaid A, Saleh D: Reduced expression of endothelial nitric oxide synthase in the lungs of patients with pulmonary hypertension. N Engl J Med 1995, 333:214-221.

5. Guo FH, De Raeve HR, Rice TW, Stuehr DJ, Thunnissen FB, Erzurum SC: Continuous nitric oxide synthesis by inducible nitric oxide synthase in normal human airway epithelium in vivo. Proc Natl Acad Sci USA 1995, 92:7809-7813.

6. Brindicci C, Kharitonov SA, Ito M, Elliott MW, Hogg JC, Barnes PJ, Ito K: Nitric oxide synthase isoenzyme expression and activity in peripheral lung tissue of patients with chronic obstructive pulmonary disease. Am J Respir Crit Care Med 2010, 181:21-30.

7. Ricciardolo FL, Caramori G, Ito K, Capelli A, Brun P, Abatangelo G, Papi A, Chung KF, Adcock I, Barnes PJ, et al: Nitrosative stress in the bronchial mucosa of severe chronic obstructive pulmonary disease. J Allergy Clin Immunol 2005, 116:1028-1035.

8. Seimetz M, Parajuli N, Pichl A, Veit F, Kwapiszewska G, Weisel FC, Milger K, Egemnazarov B, Turowska A, Fuchs B, et al: Inducible NOS inhibition reverses tobacco-smoke-induced emphysema and pulmonary hypertension in mice. Cell 2011, 147:293-305.

9. Berndt A, Leme AS, Shapiro SD: Emerging genetics of COPD. EMBO Mol Med 2012, 4:1144-1155.

10. Foreman MG, Campos M, Celedon JC: Genes and chronic obstructive pulmonary disease. Med Clin North Am 2012, 96:699-711.

11. Connett JE, Kusek JW, Bailey WC, O' Hara P, Wu M: Design of the Lung Health Study: a randomized clinical trial of early intervention for chronic obstructive pulmonary disease. Control Clin Trials 1993, 14:3S-19S.

12. Saur D, Vanderwinden JM, Seidler B, Schmid RM, De Laet MH, Allescher HD: Single-nucleotide promoter polymorphism alters transcription of neuronal nitric oxide synthase exon 1c in infantile hypertrophic pyloric stenosis. Proc Natl Acad Sci USA 2004, 101:1662-1667.

13. Burgner $D$, Usen $S$, Rockett $K$, Jallow M, Ackerman $H$, Cervino A, Pinder $M$ Kwiatkowski DP: Nucleotide and haplotypic diversity of the NOS2A promoter region and its relationship to cerebral malaria. Hum Genet 2003, 112:379-386.

14. Arif E, Ahsan A, Vibhuti A, Rajput C, Deepak D, Athar M, Singh B, Pasha MA: Endothelial nitric oxide synthase gene variants contribute to oxidative stress in COPD. Biochem Biophys Res Commun 2007, 361:182-188.

15. Pillai SG, Ge D, Zhu G, Kong X, Shianna KV, Need AC, Feng S, Hersh CP, Bakke $P$, Gulsvik A, et al: A genome-wide association study in chronic obstructive pulmonary disease (COPD): identification of two major susceptibility loci. PLOS Genet 2009, 5:e1000421.

16. Fishman A, Martinez F, Naunheim K, Piantadosi S, Wise R, Ries A, Weinmann G, Wood DE: National Emphysema Treatment Trial Research Group: A randomized trial comparing lung-volume-reduction surgery with medical therapy for severe emphysema. N Engl J Med 2003, 348:2059-2073.

17. Fishman A, Martinez F, Naunheim K, Piantadosi S, Wise R, Ries A, Weinmann G, Wood DE, National Emphysema Treatment Trial Research G: A randomized trial comparing lung-volume-reduction surgery with medical therapy for severe emphysema. N Engl J Med 2003, 348:2059-2073.
18. Bell B, Rose C, Damon H: The Normative Aging Study: an interdisciplinary and longitudinal study of health and aging. Aging Hum Dev 1972, 3:5-17.

19. Vestbo J, Anderson W, Coxson HO, Crim C, Dawber F, Edwards L, Hagan G, Knobil K, Lomas DA, MacNee W, et al: Evaluation of COPD Longitudinally to Identify Predictive Surrogate End-points (ECLIPSE). Eur Respir J 2008, 31:869-873.

20. Regan EA, Hokanson JE, Murphy JR, Make B, Lynch DA, Beaty TH, Curran-Everett D, Silverman EK, Crapo JD: Genetic epidemiology of COPD (COPDGene) study design. COPD 2010, 7:32-43.

21. Cho MH, Boutaoui N, Klanderman BJ, Sylvia JS, Ziniti JP, Hersh CP, DeMeo DL, Hunninghake GM, Litonjua AA, Sparrow D, et al: Variants in FAM13A are associated with chronic obstructive pulmonary disease. Nat Genet 2010, 42:200-202.

22. He JQ, Sandford AJ, Wang IM, Stepaniants S, Knight DA, Kicic A, Stick SM, Paré PD: Selection of housekeeping genes for real-time PCR in atopic human bronchial epithelial cells. Eur Respir J 2008, 32:755-762.

23. Livak KJ, Schmittgen TD: Analysis of relative gene expression data using real-time quantitative PCR and the $2^{-\Delta \Delta C T}$ method. Methods 2001, 25:402-408.

24. Hoffjan S, Nicolae D, Ostrovnaya I, Roberg K, Evans M, Mirel DB, Steiner L, Walker K, Shult P, Gangnon RE, et al: Gene-environment interaction effects on the development of immune responses in the 1st year of life. Am J Hum Genet 2005, 76:696-704.

25. Kang JH, Wiggs JL, Rosner BA, Hankinson SE, Abdrabou W, Fan BJ, Haines J, Pasquale LR: Endothelial nitric oxide synthase gene variants and primary open-angle glaucoma: interactions with sex and postmenopausal hormone use. Invest Ophthalmol Vis Sci 2010, 51:971-979.

26. Fernandez-Cadenas I, Mendioroz M, Domingues-Montanari S, Del RioEspinola A, Delgado P, Ruiz A, Hernandez-Guillamon M, Giralt D, Chacon P, Navarro-Sobrino $M$, et al: Leukoaraiosis is associated with genes regulating blood-brain barrier homeostasis in ischaemic stroke patients. Eur J Neurol 2011, 18:826-835.

27. Kuzmanic Samija R, Primorac D, Resic B, Lozic B, Krzelj V, Tomasovic M, Stoini E, Samanovic L, Benzon B, Pehlic M, et al: Association of NOS3 tag polymorphisms with hypoxic-ischemic encephalopathy. Croat Med J 2011, 52:396-402.

28. Ahsan A, Ram R, Baig MA, Pasha MA: ACE I allele and eNOS G allele crosstalk may have a role in chronic obstructive pulmonary disease. Clin Biochem 2004, 37:1037-1040.

29. Yildiz P, Oflaz H, Cine N, Erginel-Unaltuna N, Erzengin F, Yilmaz V: Gene polymorphisms of endothelial nitric oxide synthase enzyme associated with pulmonary hypertension in patients with COPD. Respir Med 2003, 97:1282-1288

30. Novoradovsky A, Brantly ML, Waclawiw MA, Chaudhary PP, Ihara H, Qi L, Eissa NT, Barnes PM, Gabriele KM, Ehrmantraut ME, et al: Endothelial nitric oxide synthase as a potential susceptibility gene in the pathogenesis of emphysema in a1-antitrypsin deficiency. Am J Respir Cell Mol Biol 1999, 20:441-447.

31. Demeo DL, Campbell EJ, Barker AF, Brantly ML, Eden E, McElvaney NG, Rennard SI, Sandhaus RA, Stocks JM, Stoller JK, et al: IL10 polymorphisms are associated with airflow obstruction in severe alpha1-antitrypsin deficiency. Am J Respir Cell Mol Biol 2008, 38:114-120.

32. Islam T, Breton C, Salam MT, McConnell R, Wenten M, Gauderman WJ, Conti D, Van Den Berg D, Peters JM, Gilliland FD: Role of inducible nitric oxide synthase in asthma risk and lung function growth during adolescence. Thorax 2010, 65:139-145.

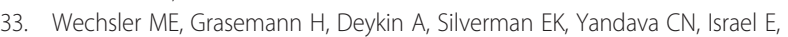
Wand M, Drazen JM: Exhaled nitric oxide in patients with asthma: association with NOS1 genotype. Am J Respir Crit Care Med 2000 162:2043-2047.

34. Ali M, Khoo SK, Turner S, Stick S, Le Souef P, Franklin P: NOS1 polymorphism is associated with atopy but not exhaled nitric oxide levels in healthy children. Pediatr Allergy Immunol 2003, $14: 261-265$

35. Storm Van's Gravesande K, Wechsler ME, Grasemann H, Silverman ES, Le L, Palmer LJ, Drazen JM: Association of a missense mutation in the NOS3 gene with exhaled nitric oxide levels. Am J Respir Crit Care Med 2003, 168:228-231.

36. Leung TF, Liu EK, Tang NL, Ko FW, Li CY, Lam CW, Wong GW: Nitric oxide synthase polymorphisms and asthma phenotypes in Chinese children. Clin Exp Allergy 2005, 35:1288-1294. 
37. Leung TF, Liu EK, Li CY, Chan IH, Yung E, Lam CW, Wong GW: Lack of association between NOS2 pentanucleotide repeat polymorphism and asthma phenotypes or exhaled nitric oxide concentration. Pediatr Pulmonol 2006, 41:649-655.

38. Salam MT, Bastain TM, Rappaport EB, Islam T, Berhane K, Gauderman WJ, Gilliland FD: Genetic variations in nitric oxide synthase and arginase influence exhaled nitric oxide levels in children. Allergy 2011, 66:412-419.

39. Dahgam S, Nyberg F, Modig L, Naluai AT, Olin AC: Single nucleotide polymorphisms in the NOS2 and NOS3 genes are associated with exhaled nitric oxide. J Med Genet 2012, 49:200-205.

40. Bouzigon E, Monier F, Boussaha M, Le Moual N, Huyvaert H, Matran R, Letort S, Bousquet J, Pin I, Lathrop M, et al: Associations between nitric oxide synthase genes and exhaled NO-related phenotypes according to asthma status. PLOS ONE 2012, 7:e36672.

41. Sadeghi-Hashjin G, Folkerts G, Henricks PA, Muijsers RB, Nijkamp FP: Peroxynitrite in airway diseases. Clin Exp Allergy 1998, 28:1464-1473.

doi:10.1186/1471-2466-13-64

Cite this article as: Aminuddin et al:: Nitric oxide synthase

polymorphisms, gene expression and lung function in chronic

obstructive pulmonary disease. BMC Pulmonary Medicine 2013 13:64.

\section{Submit your next manuscript to BioMed Central and take full advantage of:}

- Convenient online submission

- Thorough peer review

- No space constraints or color figure charges

- Immediate publication on acceptance

- Inclusion in PubMed, CAS, Scopus and Google Scholar

- Research which is freely available for redistribution 